\title{
Havayolu Marka Kişiliği Algısının Geleneksel ve Nöropazarlama Yöntemleri İle Karşılaştırılmasına Yönelik Bir Uygulama*
}

\section{An Application for Comparing Airline Brand Personality Perception with Traditional and Neuromarketing Methods}

\author{
Şahap Akan, ${ }^{\text {*** }}$ Özlem Atalık, ${ }^{\mathrm{b}}$ Nurcan Yücel ${ }^{\mathrm{c}}$ \\ ${ }^{a}$ Arş. Gör., Eskişehir Teknik Üniversitesi, Havacılık ve Uzay Bilimleri Fakültesi, Havacılık Yönetimi Bölümü, 26470, Eskişehir/Türkiye. \\ ORCID: 0000-0002-4633-4683

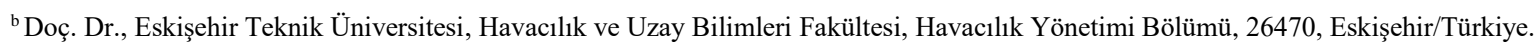 \\ ORCID: 0000-0003-4249-2237

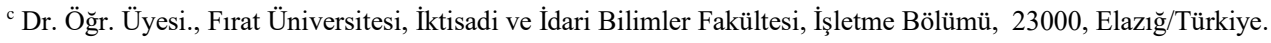 \\ ORCID: 0000-0003-2915-2334
}

\section{MAKALE BİLGİSI}

\section{Makale Geçmişi:}

Başvuru tarihi: 11 Ekim 2018

Düzeltme tarihi: 26 Kasım 2018

Kabul tarihi: 21 Ocak 2019

\section{Anahtar Kelimeler:}

Nöropazarlama

EEG

Marka Kişiliği

Havayolları

\section{ARTICLE INFO}

\section{Article history:}

Received 11 October 2018

Received in revised form 26 Nocember 2018

Accepted 21 January 2019

\section{Keywords:}

Neuromarketing

EEG

Brand Personality

Airlines
ÖZ

Günümüzde araştırmacılar bilimsel alandaki çeşitli sorulara cevap bulabilmek için disiplinler arası alanlara ilgi duymaya başlamıştır. Bu kapsamda pazarlama ile nörobilimi bir araya getiren, nöropazarlama tekniklerinin, tüketicilerin gerçek duygularını ve düşüncelerini belirlemenin en etkin yollarından biri olduğu ifade edilmektedir. Bu çalışmada; Türkiye'de faaliyet gösteren Kırmızı Havayolları ile Sarı Havayolları'nın marka kişilik özellikleri anket ve nöropazarlama tekniklerinden EEG Analiz Yöntemi kullanılarak belirlenmiş ve her iki yöntem karşılaştırılmıştır. Çalışmanın ilk aşamasında; 32 gönüllü katılımcıya her iki havayoluna ilişkin marka kişiliği sıfatları gösterilmiş ve bu sıfatlara ilişkin tepkileri ölçümlenmiştir. Çalışmanın ikinci aşamasında ise; Aaker tarafindan geliştirilen ve 42 marka kişiliği sıfatından oluşan marka kişiliği skalasını gönüllü katılımcıların her iki havayoluna göre cevaplandırmaları istenmiştir. Çalışmanın sonucunda her iki yöntemden elde edilen bulguların büyük oranda farklılık gösterdiği saptanmıştır.

\section{A B S T R ACT}

Nowadays, researchers are interested in multidisciplinary fields to find answers to various questions in the scientific field. In this context, it has been stated that neuromarketing techniques, which combine marketing and neuroscience and provide the opportunity to find answers to many questions in different areas of marketing, are one of the most effective ways of determining the real feelings and thoughts of consumers. In this study; brand personality features of Red Airlines and Yellow Airlines operating in Turkey are determined using the survey and EEG Analysis Method, one of the neuromarketing techniques and then, both methods are compared. In the first phase of the study; the features of brand personality for both airlines are shown to 32 volunteer participants and their reactions to these attributes are measured. In the second phase of the study; the brand personality scale, which was developed by Aaker and composed of 42 brand personality, is asked to the voluntary participants for both airlines. Consequently, it is found that the findings of both methods differ significantly.

*Bu çalışma yazarın 2017 yılında Doç. Dr. Özlem ATALIK ve Dr. Öğr. Üyesi Nurcan YÜCEL danışmanlığında Anadolu Üniversitesi Sosyal Bilimler Enstitüsü Sivil Havacılık Anabilim Dalı'nda yapılan "Havayolu marka kişiliği algısının yüz yüze görüşme ve nöropazarlama yöntemlerinden EEG ile karşılaştırılması: Bir uygulama" başlıklı yüksek lisans tezinden üretilmiştir.

** Sorumlu yazar/Corresponding author

e-posta: sakan@anadolu.edu.tr 


\section{Giris}

Bilgi ve iletişim teknolojilerinin gelişmesi, rekabetin artması, tüketicilerin bilinçlenmesi ve küreselleşme gibi birçok faktör pazarlama anlayışııın değişiminde önemli rol oynamışlardır.Pazarlama anlayışı; son 60 yılda ürün merkezli yaklaşımdan (pazarlama 1.0) tüketici merkezli yaklaşıma (pazarlama 2.0) geçmiş, günümüzde ise değere odaklı yaklaşıma doğru (pazarlama 3.0) bir dönüşüm süreci yaşamıştır. Değere odaklı pazarlama yaklaşımı insanları sadece tüketen varlıklar olarak değil, ruhu, aklı ve duyguları olan "insanlar" olarak yaklaşmaktadır. Dolayısıyla, insanların tüketim ihtiyaçlarının yanında, diğer ihtiyaçlarının da göz ardı edilmediği ve bütünsel olarak değerlendirildiği bir döneme girilmiştir(Kotler, 2011).

Pazarlama anlayışındaki bu değişimlere paralel olarak işletmeler de daha bilinçli tüketiciler ile karşı karşıya kalmışlardır. Bu doğrultuda pazarlama akademisyenleri ve uygulamacıları da tüketicilerin pazarlama uyaranlarına gösterdiği tepkileri ve bu tepkilerin arkasında yatan gerçek sebepleri anlamak amacıyla farklı pazar araştırması araçlarından faydalanmaya başlamıştır. Bu araştırmalardan elde edilen veriler tüketicilerin daha iyi anlaşılması ve işletmelerin daha etkin pazarlama stratejileri geliştirmesi bakımından oldukça önem arz etmektedir (Yücel, 2016).

Geleneksel yöntemler, tüketicilerin davranışlarını çözümleme noktasında tüketiciler ile işbirliğine ve tüketicilerin kendilerini ifade edebilme yeterliliklerine ihtiyaç duymaktadır. Ancak son yıllarda yapılmış çeşitli çalışmalar tüketici kararlarının çoğunda bilinç öncesi alınan kararların etkili olduğu sonucunu ortaya çıkarmıştır. $\mathrm{Bu}$ bağlamda da geleneksel yöntemlerin yetersiz kaldığıdüşünülmektedir. Geleneksel pazar araştırmalarının ve yöntemlerinin etkin ve doğru sonuçlar üretememesi pazarlama profesyonellerini nöropazarlama gibi yeni ve farklı alanlara yöneltmiştir(Özkara, 2017). Yapılacak araştırmalarda Nöropazarlama tekniklerinin kullanılmasının tüketicilerin bilinçaltı ve bilinç düzeyindeki gerçek duygu ve düşüncelerini ortaya çıkarmak adına en doğru ve tutarlı yöntemlerden biri olarak görülmektedir.

$\mathrm{Bu}$ çalışmada; Türk Sivil Havacılık sektöründe faaliyet gösteren Kırmızı ve Sarı Havayolları'nın marka kişiliklerinin geleneksel yöntemlerden anket ile nöropazarlama yöntemlerinden EEG Analiz Yöntemiyle ölçümlenmesi ve her iki yöntemin karşılaştırılması amaçlanmıştır. Araştırmanın sonuçlarının herhangi yanlış anlamaya sebep olmaması için havayolu işletmeleri Kırmızı ve Sarı Havayolları olarak kodlanmıştır. Kırmızı Havayolları ülkemizde geleneksel taşıyıcı modeli ile faaliyet gösteren en büyük havayollarından biridir. Sarı Havayolları ise düşük maliyetli taşıyıcı modeli ile faaliyetlerini sürdüren bir havayolu işletmesidir. Çalışmada; ilk olarak nöropazarlama ve marka kişiliği yaklaşımı hakkında kısaca bilgi verilerek ilgili bölümlere ilişkin literatür taramasına yer verilmiştir. Ardından EEG analiz yöntemi açıklanarak, çalı̧̧madaki deneysel yöntem ile deneyden elde edilen bulgular ve bulgulara ilişkin sonuçlar ortaya konulmuştur.

\section{Kavramsal Çerçeve}

\subsection{Nöropazarlama}

Nöro ve Pazarlama sözcüklerinin bir araya gelerek oluşturulduğu nöropazarlama kavramı "pazar ve pazarlama değişimleriyle ilgili olarak insan davranışlarını anlamak ve analiz edebilmek için nörobilimsel yöntemlerin uygulaması" olarak tanımlanmaktadır. (Lee vd., 2007).Nörolojik ve fizyolojik tarama teknolojileri ile pazarlama stratejilerinin birleşmesi anlamında kullanılmakta olan nöropazarlama; tüketicileri daha iyi anlayabilmek amaciyla pazarlama profesyonellerinin kullandığı bir yöntem olarak ifade edilmektedir(Tüzel, 2010).

Nöropazarlama; fizyolojik ve beyinsel ölçümler vasıtasıla tüketici satın alma davranışı kararlarına ilişkin beynin hangi bölgelerinde hareketlenme olduğunu ya da hangi fizyolojik tepkilerin verildiğini tespit etme hususunda etkili yollardan biri olarak kabul edilmektedir. Nöropazarlama, tüketici tercihlerinin arkasındaki asıl nedenleri ortaya çıkarırken elde edilen bulgular ile yeni anlamlar inşa etmeye olanak sağlamaktadır (Ural, 2008).

Nöropazarlama; sadece tüketici satın alma davranışı kararları temelinde kullanılan bir yöntem olarak görülmemektedir. Tüketicilerin tercihlerinin yanında sosyal davranışlarının da hangi biyolojik temellere dayandığını deneysel olarak test edebilme imkânı sunarak siyaset pazarlamasından reklam sloganlarının belirlenmesine, markalamadan ambalaj tasarımına kadar pek çok farklı alanda ve disiplindeki çalışmalara araştırma yapma imkânı sağlamaktadır (Yücel ve Çubuk, 2014).

Nöropazarlama; çeşitli alanlardan farklı disiplinlerin bir araya gelerek oluşturduğu bir multidisipliner alan olarak ifade edilmektedir. $\mathrm{Bu}$ disiplinler arasinda biyoloji, nörofizyoloji, nöroloji ve bilişsel bilimlerin sayılması mümkündür. Literatür taramalarında nöropazarlamanın pazarlama, nörobilim ve psikoloji çatısı altında toplandığ görülmektedir (Akın ve Sütütemiz, 2014). Nöropazarlamayı bir bilim dalı olarak adlandırmak yanlış olsa da, yukarıda belirtilen üç disiplin arasında faaliyet gösteren bir alan olduğunu belirtmek mümkündür. (Erdemir ve Yavuz, 2016).

Nöropazarlama araştırmaları yapılırken nörobilimin kullandığı çeşitli teknikler kullanılmaktadır. Bu teknikler sadece beyinsel aktiviteleri değil, aynı zamanda fizyolojik aktiviteleri de ölçümlemeyerek araştırmacıların farklı teknikleri ayrı ayrı ya da birlikte kullanmalarına olanak sağlamaktadır. Nöropazarlama araştırmalarında sıklıkla kullanılan teknikler arasında; Fonksiyonel Manyetik Rezonans Görüntüleme (fMRI), Elektroansefalografi (EEG), Pozitron Emisyon Tomografisi (PET),Magnetoensefalografi (MEG), Göz izleme, Yüz kodlama ve Galvanik Deri Tepkisi (GSR) bulunmaktadır (Fortunato vd., 2014).

- fMRI; herhangi bir uyaran karşısında insan beyninin iç kısımlarında meydana gelen anlık hareketlenmeleri üç boyutlu haritalar hâlinde sunmaktadır (Poldrack vd., 2011).

- EEG; serebral korteksteki postsinaptik potansiyellerden kaynaklanan ve kafa derisinin 
yüzeyinde meydana gelen elektriksel potansiyel değișimlerini kaydetmektedir (Yücel ve Çubuk, 2014).

- PET; fMRI tekniği ile çeşitli benzerlikler göstermekle birlikte, katılımcılara radyoaktif madde enjekte edilmesiyle insan beyninin iç kısımlarının görüntülenmesine imkân sağlamaktadır (Fortunato vd., 2014).

- MEG; beyindeki elektriksel aktivitelerin neden olduğu manyetik alanlardaki küçük değişiklikleri kafa derisi üzerine yerleştirilmiş birçok sensörle ölçümleyen beyin görüntüleme tekniğidir (Hansen vd., 2010).

- Göz izleme; adından da anlaşılacağı gibi insanların nereye baktıklarını tespit etmeye yarayan bir tekniktir(Özdoğan, 2008).

- Yüz okuma; bir yazılım vasitasiyla uyaran karşısındaki yüz ifadelerinden yola çıkarak o andaki duygusal tepkileri ölçümlemektedir (Erdemir ve Yavuz, 2016).

- GSR; parmak uçlarına yerleştirilen sensorlar vasıtasıyla derideki elektriksel yayılımın büyüklüğünü ölçümleyerek uyaranın yarattı̆ğ duygusal şiddeti tespit edilebilmektedir (Erdemir ve Yavuz, 2016).

1990'l y yllarda Coca-Cola ve Ford gibi çok uluslu pek çok işletme pazarlama faaliyetlerinde farklı nöropazarlama tekniklerini kullanmış ancak bu araştırmalarda elde edilen bulguları ticari bir sır olarak saklamışlardır(Çakar, 2011). Ancak, 1990'lı yılların sonunda Gerry Zaltman'ın fMRI tekniğini pazarlama araştırmalarında kullanmaya başlamasından sonra kavramın popülaritesi artmıştır (Fisher vd., 2010).

Nöropazarlamaya ilişkin yapılmış ilk bilimsel araştırma Baylor Tıp Merkezi'nde Read Montague ve arkadaşları tarafindan 2004 y1lında gerçekleştirilmiştir. Bu araştırmada; katılımcılar Pepsi ve Coca-Cola içeceklerine ilişkin bir tadım testine tabi tutulmuşlardır. Test esnasında fMRI tekniği ile beyin tarama işlemi yapılmış ve katılımcıların beyin aktivasyon haritaları elde edilmiş veyapılan analiz sonucunda tüketicilerin iki markadan birini seçmelerinin altında yatan sebeplerin neler olduğu araştırılmıştır. İki safhadan oluşan araştırmada katılımcıların ilk olarak markaları bilmeden içtikleri kör tadım testinde Pepsi'yi tat olarak Coca-Cola'ya göre daha fazla tercih ettikleri gözlemlenmiştir. İkinci safhada markayı görerek tadım testine tabi olan katılımcıların Coca-Cola'yı daha fazla tercih ettikleri görülmüş̧ür. Araştırmanın sonucunda marka ile bellek arasındaki ilişkinin, satın alma tercihleri üzerinde önemli derecede etkili olduğu sonucuna ulaşılmıştır (McClure vd., 2004).

2004 yılında yapılan ilk nöropazarlama çalışmasından itibaren nöropazarlamaya olan ilgi yıllar içerisinde artmış ve Tablo 1'de görüldüğü gibi pazarlamanın pek çok alanında nöropazarlama çalışmaları yürütülmüştür. Ancak, bu konuların yanında marka kişiliğiyle ilgili sınırlı sayıda çalışmaya rastlanmıştır (Öztürk vd., 2018; Yoon vd., 2006).
Tablo 1. Nöropazarlamaya İlişkin Bazı Çalışma Konuları

\begin{tabular}{ll}
\hline \multicolumn{1}{c}{ Nöropazarlama Konuları } & \multicolumn{1}{c}{ Yazarlar } \\
\hline Ürün Ambalaj ve Paket Tasarımı & $\begin{array}{l}\text { (Khushaba vd., 2013; Barré, } \\
\text { Afonso-Jaco vd., 2015) }\end{array}$ \\
\hline Reklam & $\begin{array}{l}\text { (Ohme vd., 2009; Vecchiato } \\
\text { vd., 2011; Astolfi vd., 2008; } \\
\text { Morris vd., 2009) }\end{array}$ \\
\hline Film Fragmanı Etkinliği & (Boksem ve Smidts, 2015) \\
\hline Marka Genişlemesi & (Ma vd., 2008; Ma vd., 2007; \\
& Ma vd., 2010; Wang vd., \\
& $2012)$ \\
\hline Marka Seçimi & (Hillenbrand vd., 2013; Santos \\
\hline Marka Sadakati & (Lin vd., 2011) \\
\hline Satın Alma Kararları & (Po vd., 2013; Taqwa vd., \\
\hline Web Sitelerinin Etkinliği & 2015) \\
\hline Marka Bağlılığı & (Shamir ve Ahmadi, 2016) \\
\hline
\end{tabular}

\subsection{Marka Kişiliği}

Bir marka ile ilişkili ve bir markaya uygulanabilir bir dizi insan kişiliği özelliği olarak tanımlanan (Azoulay ve Kapferer, 2003)marka kişiliği, markaların da insanlar gibi bir takım duygu ve kişilik özelliklerine sahip olduğu varsayımına dayandırılmıştır(Uztuğ, 2003). Bu varsayıma dayanarak yapılan araştırmalar sonucunda, tüketicilerin kendilerine yakın gördükleri, kendilerini rahat hissettikleri ve risk değerlendirmesi açısından daha az tehlike arz eden markalara kişilik atfettikleri sonucuna varılmıştır (Yener, 2007). Tüketicilerin kendilerini yakın hissettikleri markaları kişileştirme eğiliminde bulunmaları ve işletmelerin ezici rekabet ortamında daha güçlü markalar oluşturma eğiliminde olmaları ise marka kişiliğinin önemini daha fazla artırmıştır(Aysan vd., 2012).

Marka kişiliği, markalara insani kişilik özelliklerinin atfedilmesi sonucunda oluşmaktadır. Başka bir deyişle marka kişiliği "Marka, eğer bir insan olsaydı hangi kişilik özelliklerine sahip olurdu?" sorusunun yanıtını ifade etmektedir. $\mathrm{Bu}$ doğrultuda yapılan araştırmalar farklı markaların farklı kişilik özelliklerine sahip olduğunu göstermiştir. Örneğin, Mr. Coffee entelektüel ve arkadaş canlısı bir marka olarak değerlendirilirken Harley Davidson sert ve dışadönük bir marka olarak değerlendirilmiştir. Dolayısıyla bu markalar, tüketicilerin zihninde sadece ürün olarak değil farklı insani özelliklere sahip markalar olarak da algılanarak ayrıcalıklı bir konuma erişmektedir (Yücel ve Halifeoğlu, 2017).

Marka kişiliği kavramının oluşumu hem tüketicilerin hem de işletmelerin içinde bulunduğu çift yönlü bir süreci ifade etmektedir. $\mathrm{Bu}$ süreçte işletmeler markalarının sahip olmasını istediği marka kişiliği özelliklerini çeşitli iletişim kanalları vasıtasıyla tüketicilerine aktarmakta ve tüketiciler nezdinde markaya ilişkin algılanan kişilik özellikleri dizisi oluşmaktadır (Aysan vd., 2012). Bu durumda marka kişiliğgi özellikleri tüketicilerin markaya ilişkin algılarından ve atfettiği marka kişiliği özelliklerinden oluşmaktadır. 
Dolayısıyla, gerçek marka kişiliği özellikleri aslında tüketicilerin zihinlerinde inşa ettikleri anlamlar ile özdeşleşmektedir (Boyraz ve Balım, 2015).

Markaların kişilik özelliklerini kantitatif ve kalitatif yöntem ile ölçümlemek mümkündür. Ancak, Aaker tarafindan geliştirilen "marka kişiliği skalası en bilinen ve tercih edilen yöntemlerin başında gelmektedir(Kalemci, 2015).Jennifer Aaker 1997 yılında yaptığı çalışmasında; "Markalar hangi kişilik özelliklerine sahip olabilirler?" sorusundan hareketle bir marka kişiliği skalası geliştirmiştir. Şekil 1'de görüldüğü gibi marka kişiliği skalası 5 boyut (samimiyet, coşku, yeterlilik, çok yönlülük, sağlamlık) ve 15 özellik (gerçekçi, dürüst, erdemli, neşeli, cesur, canlı, yaratıcı, çağdaş, güvenilir, zeki, başarılı, üst sınıf, çekici, dışa dönük, sert) ve 42 marka kişiliği sıfatından meydana gelmiştir (Şekil 1)(Aaker, 1997).

Şekil 1. Marka Kişiliği Ölçeği

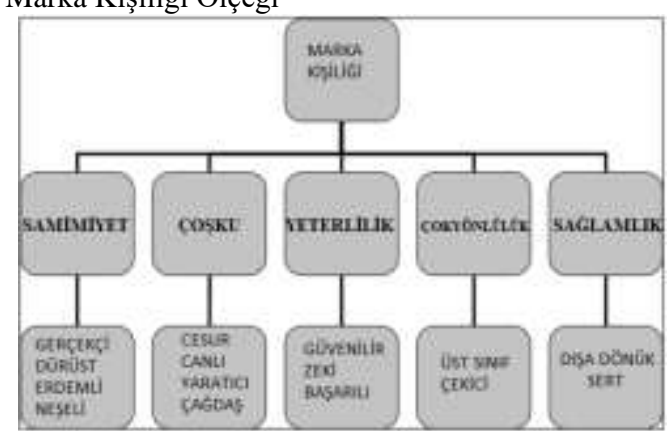

Kaynak: Aaker (1997)

Marka kişiliğinin rakiplerine göre farklılık yaratması, tüketicilerin duygusal kararlarını etkilemesi ve diğer pazarlama faaliyetlerine fayda sağlaması dolayısıyla Aaker tarafından geliştirilen marka kişiliği skalası çeşitli alanlardaki marka kişiliği çalışmalarında kullanılmıştır (Lee vd., 2009; Guzmán ve Paswan, 2009; Köse vd., 2015; Boyraz ve Balım, 2015). Bu kapsamda, havayolu işletmeleri ile ilgili sadece geleneksel yöntemler kullanılarak yapılanmarka kişiliği çalışmaları da bulunmaktadır.

Kotsi ve Valek'in(2018)Etihad ve Emirates havayolu işletmelerinin reklam kampanyalarının tüketicilerde yarattığı görsel algılarına yönelik bir marka kişiliği çalışması yürütmüştür. Araştırma sonucunda; Etihad ve Emirates beş marka boyutunun üçünde (samimiyet, heyecan, yeterlilik) önemli derecede farklılık gösterdiği ortaya konulmuştur.

Karoubi ve Noghan (2014); İran'da faaliyet gösteren İran Air ile Mahan Air'in marka kişiliğgine ilişkin bir çalışma gerçekleştirmiştir. Özel bir havayolu işletmesi olan Mahan Air'inbeş marka kişiliği boyutunun tümünde devlet sahipliğindeki İran Air'e üstünlük sağladığı ortaya konulmuştur.

Özer ve Ersoy (2012); Türkiye'de faaliyet gösteren beş havayolu işletmesinin marka kişiliği algılarını belirlemeye çalışmıştır. Araştırma sonucunda birinci havayolunun samimiyet, heyecan, yeterlilik, çok yönlülük ve sağlamlık boyutlarında, ikinci havayolunun samimiyet boyutunda, üçüncü havayolunun samimiyet ve yeterlilik boyutlarında, dördüncü havayolunun heyecan boyutunda, beşinci havayolunun ise yeterlilik boyutunda algılandığı ortaya konulmuştur.

\section{Yöntem}

\subsection{Araştırmanın Amacı}

$\mathrm{Bu}$ araştırmanın amacı; Türkiye'de faaliyet gösteren Kırmızı Havayolları ile Sarı Havayolları'nın marka kişilik özelliklerinin anket ve nöropazarlama tekniklerinden EEG analiz yöntemi kullanılarak belirlenmesi ve her iki yöntemin karşılaştırılmasıdır.

\subsection{Araştırmanın Örneklemi}

Araştırma; Fırat Üniversitesi İktisadi ve İdari Bilimler Fakültesi öğrencilerinden 32 gönüllü katılımc1 ile yapılmıştır. Gönüllü katılımcıların yaş aralığı 20-25 arasında olup, 8'inin kadın 24'ünün erkek olduğu tespit edilmiştir. Katılımcıların farklı zamanlarda hem Kırmızı hem de Sarı Havayolları'nı kullandıklarına ilişkin sözlü beyanları alınmış ve örneklem grubu bu doğrultuda belirlenmiştir. Hem anket formunu cevaplayan hem de EEG ölçümlerine katılan örneklem grubunun 32 kişi ile sınırlandırılmasının iki nedeni bulunmaktadır. Bunlardan birincisi; Stephen F. Sands'ın EEG analiz yönteminde optimum örneklem sayısının belirlenmesine ilişkin yaptığı çalışmasında 30-40 kişi arasındaki örneklem gruplarının EEG ölçümleri için \%1'den daha düşük bir hata payı ile en optimum ve tutarlı örneklem sayısını vermiş olmasıdır(Sands, 2009). İkincisi ise; EEG analiz yönteminde hem katılımcı başına maliyetinin yüksek olması hem de verilerin analizinin fazla zaman almasıdır.

\subsection{Araştırmanın Sınırlı1ıkları}

Araştırma kapsamında kullanılacak cihazların Fırat Üniversitesi Pazarlama ve Nöropazarlama Araştırma Merkezi'nde (FÜPNAM) olması nedeniyle, örneklemin Fırat Üniversitesi İktisadi ve İdari Bilimler Fakültesi öğrencilerinden seçilmiş olması, araştırmanın kapsamını Türkiye'de faaliyet gösteren Kırmızı ve Sarı Havayolları'nın oluşturması, katılımcıların marka kişiliği sıfatlarına ilişkin herhangi bir tepki göstermemesi ve deney sırasında oluşan artefektler araştırmanın sınırlılıklarını oluşturmaktadır.

\subsection{Araştırmanın Yöntemi}

Araştırmada; nöropazarlama yöntemlerinden EEG analiz yöntemi ve geleneksel yöntemlerden anket yöntemi birlikte kullanılmış ve araştırma iki aşamada gerçekleştirilmiştir. İlk aşamada; gönüllü katılımcılara EEG cihazı yerleştirilerek her iki havayolununAaker'in marka kişiliği ölçeğine göre belirlenmiş 42 farklı sıfatı içeren marka kişiliği görselleri izlettirilmiş ve katılımcıların bu uyaranlara ilişkin beyinsel tepkileri ölçümlenmiştir. İkinci aşamada ise; katılımcılardan bu havayollarına ilişkin Aaker'in marka kişiliği ölçeğine göre belirlenmiş olan marka kişiliği ifadelerini markalarla özdeşleştirdikleri şekilde anket formu ile cevaplamaları istenmiştir.

Araştırmanın ilk aşamasında; nöropazarlama çalışmalarında sıkça kullanılan ve nörobilim yöntemlerinden biri olan EEG analiz yöntemi kullanılmıştır. EEG yöntemi; serebral korteksteki senkronize postsinaptik potansiyellerden kaynaklanan, kafa derisinin yüzeyinden kaydedilebilen elekriksel potansiyel değişimlerinin elektriksel yöntemlerle 
izlenmesidir (Yücel ve Çubuk, 2014). EEG yöntemi vasıtasıyla beyinde meydana gelen elektriksel değişimler ölçülebilmekte ve bu sayede uyaranlara ilişkin tepkiler ortaya çıkarılabilmektedir (Freeman ve Quiroga, 2013). EEG yöntemi nöropazarlama çalışmalarında fMRI yönteminden sonra en fazla tercih edilen yöntemdir. Çünkü basit ve düşük maliyetli bir yöntemdir. Öte yandan bilişsel süreçlere ilişkin tepkileri anlık olarak milisaniye bazında ölçme ve değerlendirebilme imkânı sunmaktadır (Bercea, 2013).

Araştırmada EEG tepkilerinin ölçümlenmesinde 14 kanallı yüksek çözünürlüklü ve kablosuz olarak veri alıp işleyebilen Emotiv Epoc cihazı seçilmiştir. Emotiv Epoc cihazının tercih edilmesinin nedeni; bu cihazın pek çok çalışmada kullanılmış olmasıdır (Khushaba vd., 2013; Berčík vd., 2015). Emotiv Epoc cihazı uluslararası 10 -20 sistemine göre tasarlanmış olup, bu cihaza ilişkin elektrotların serebral korteks üzerine yerleşimi şu şekildedir; AF3, F7, F3, FC5, T7, P7, O1, O2, P8, T8, FC6, F4, F8, AF4'tür. Harf olarak gösterilen sembollerden F: Frontal(Ön), P: Parietal (yan), O: Oksipital (arka), T: Temporal (Şakak), A: Ön Frontal anlamına gelmektedir.

Şekil 2. Emotiv Epoc Cihazını Serebral Korteksteki Yerleşimi

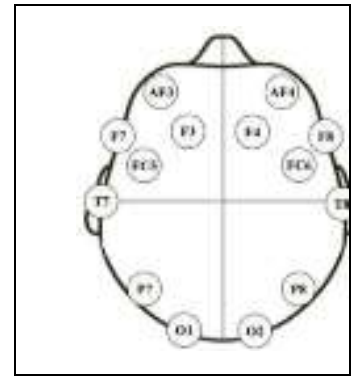

Kaynak: Mehmood ve Lee (2016)

Emotiv Epoc cihazı katılımcıların tepkilerini belirli algoritmalar dâhilinde ölçmekte ve katılımcıların duygusal tepkilerini ortaya koymaktadır. Yüksek çözünürlüklü bir cihaz olan Emotiv Epoc saniyede $2048 \mathrm{~Hz}$ frekansta veri toplarken verilerin yorumlanması safhasinda Delta (4 Hz'den düşük), Teta (4-8 Hz), Alfa (8-12 Hz) ve Beta (13$30 \mathrm{~Hz}$ ) değer aralıkları referans alınmaktadır.

Şekil 3. Epoc Emotiv Cihazı

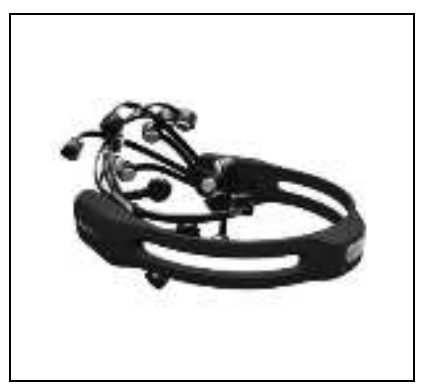

Araştırmanın ilk aşamasında; katılımcıların havayolu marka kişiliği görsellerine ilişkin tepkilerini ölçebilmek için marka kişiliği sıfatları Power Point sunumu yardımıyla görselleştirilmiştir. İlk slayt; katılımcıların kendilerini rahat hissedebilmeleri için 3 saniye boş bırakılmıştır. İkinci slaytta katılımcıların Kırmızı Havayolları'nı anımsayabileceği görsellere yer verilerek bu havayoluna odaklanmaları amaçlanmıştır. Üçüncü slaytta ise; Kırmızı Havayolları'na ilişkin uçak ve logonun olduğu "Kırmızı
Havayolları İnsan Olarak Düşünüldüğünde Sizce Hangi Kişilik Özelliklerine Sahip Olurdu?” cümlesi konumlandırılmıştır. Ardından 5 saniyelik bir geçiş slaytı yerleştirilmiş ve 3'er saniyelik periyotlarla Kırmızı Havayolları'nın Aaker tarafından önerilmiş 42marka kişiliği görseli tek tekoluşturulmuştur. Bu görsellerde beyaz zemin üzerine siyah renkle yazılmış olan marka kişiliği sıfatı slaytın orta kısmına konumlandırılmış ve ilgili marka kişiliği sıfatı üzerine Kırmızı Havayolu'nun logosu yerleştirilmiştir. Daha sonra aynı süreç Sarı Havayolları için de gerçekleştirilerek toplamda her iki havayolunu da kapsayan 282 saniyelik bir görsel hazırlanmıştır. Gerekli hazırlıklar yapıldıktan sonra Firat Üniversitesi Pazarlama ve Nöropazarlama Araştırma Merkezi (FÜPNAM)'nde deney aşamasına geçilmiştir. Bu aşamada; EEG analiz yöntemi için katılımcıların kendilerini rahat hissedebilecekleri bir ortam hazırlanmıştır. Bu ortamda çeşitli artefektlerin oluşumunu önlemek için gerekli itina gösterilmiş ve uygun şartlar sağlandıktan sonra katılımcılar laboratuvara kabul edilerek nasıl davranmaları gerektiği konusunda bilgilendirilmiştir. Katılımcıların deney esnasında hiçbir işlem yapmadan veya hareket etmeden sabit bir şekilde ekrana gelecek görselleri izlemeleri istenmiş ve izleyecekleri slayt görselleri hakkında herhangi bir bilgi verilmemiştir. Bu süreçte katılımcılardan herhangi bir beyan beklenmeden sadece marka kişiliği sıfatlarından oluşan sunuyu takip etmeleri istenmiştir.Katılımcıların özellikle ellerini bacaklarının üzerine koymaları ve artefektlere neden olabilecek baş hareketlerinden kaçınmaları konusunda uyarılmıştır. Daha sonra katılımcılar ekran karşısına oturtularak Emotiv Epoc cihazı kafa derisinin uygun bölgelerine yerleştirilmiştir.

Görsel 1. Emotiv Epoc Cihazının Kafa Derisine Yerleştirilme Aşaması

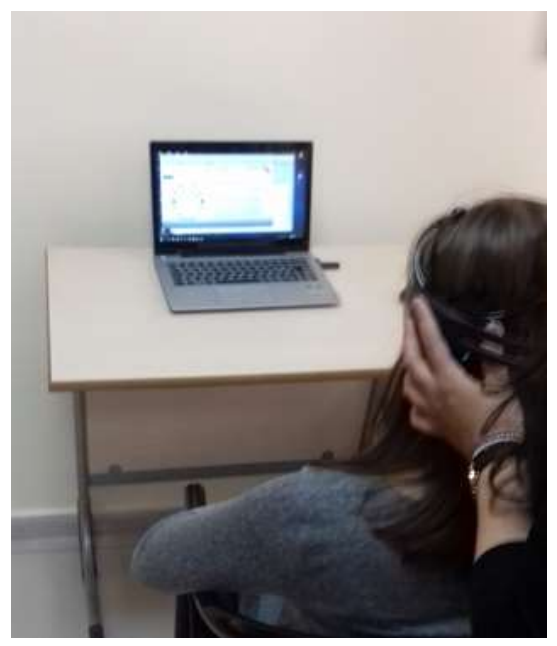

Epoc Emotiv cihazının kafa derisi üzerine doğru yerleştirilip yerleştirilmediği sistemin bir ara yüzü olan Emotiv Testbennch programı yardımı ile kontrol edilmiştir. $\mathrm{Bu}$ süreçte kafa derisine doğru yerleştirilen elektrotlardan yeşil sinyal alınarak tüm elektrotların bu yolla kontrolleri sağlanmış ve bu kontrollerden sonra deney aşamasına geçilmiştir.Şekil 4'te Emotiv Epoc cihazının serebral kortekse doğru yerleşimi gösterilmiştir. 
Şekil 4. Emotiv Epoc Cihazının Serebral Kortekse Doğru Yerleşimi

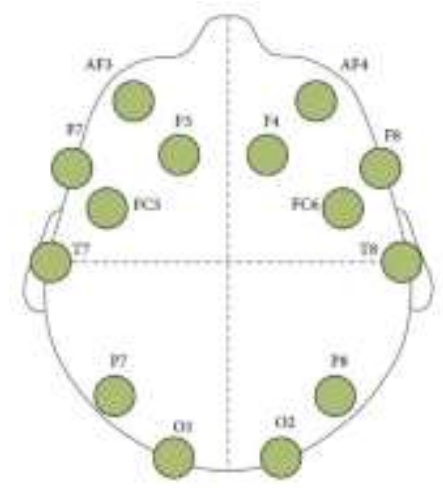

Kaynak: Choi vd. (2014)

Katılımcılardan EEG verileri elde edildikten sonra bu verilerin yorumlanması aşamasına geçilmiştir. Araştırmasonunda her bir katılımcıya ait tepkiler, EEG uzmanı ve nöropazarlama alanında faaliyet gösteren öğretim üyeleri ile değerlendirilmiştir. Katılımcılara ait beyin aktivite haritaları incelenirken herhangi bir dönüşüm yapılmamıştır. Katılımcıların beyin aktivite haritalarına ait artefaktlar belirlenirken EEG uzmanının tecrübelerinden faydalanılmıştır. EEG uzmanı tarafından artefaktların temizlenmesi, filtreleme ve artefaktlar hakkındaki düzeltmelerin yapılması ile ilgili gerekli işlemler yapılmıştır. Böylece, hangilerinin gerçek bir tepki hangilerinin artefakt olduğu tespit edilmiş ve daha net bir veriye ulaşı1mıștır.

Artefaktlerin temizlenmesinden sonra elde edilen verilerin incelenmesi aşamasına geçilmiştir. $\mathrm{Bu}$ aşamada katılımcıların vermiş oldukların tepkiler tek tek belirlenmiş ve bu tepkilerin 42 adet marka kişiliği görsellerinden hangisine ait olduğu tespit edilmiştir. Katılımcılara ait tepkiler ile görseller eşleştirilmiş ve eşleştirme sonucunda katılımcıların tepki verdikleri görseller ile marka kişilik sıfatları belirlenmiştir. Araştırmada; EEG Analiz yönteminde kullanılan program Biometric Software Suite Basic Edition lisanslı programı kullanılmıştır. Bu program dâhilinde tepkilerin belirlenmesinde sadece Teta dalga boyu dikkate alınmıştır. Zira Teta dalgası hafıza etkinliği gibi içsel olarak odaklanılmış bilişsel süreçlerde meydana gelmektedir (Genco vd., 2013). Dolayısıyla katılımcıların marka kişiliği ile havayollarını eşleştirmelerinin bilişsel bir süreci ifade edebileceği düşünülmüştür. $\mathrm{Bu}$ sebeple, bu araştırmada tepkilerin Teta dalga boyundaki Frekans dalgası referans alınmıştır.

Artefektler; serebral kaynaklı olmayan ve gerçekte kayıt edilmek istenen aktivitelerin dışında kalan ve kayda dâhil olan tüm sinyaller olarak tanımlanmaktadır. Artefektler EEG verilerinin yanlış yorumlanmasında en önemli nedenlerinden biri olarak kabul edilmektedir. Göz kırpma ve diğer göz hareketleri, terleme etkisi, kas kasılması ve hareket artefektleri en fazla karşılaşılan artefektlerin başında gelmektedir. $\mathrm{Bu}$ sebeple, EEG verilerinin doğru yorumlanmasında artefektlerin minimum düzeye indirilmesi önemli bir unsur olarak görülmektedir.

İlk aşamada; EEG verilerinin elde edilmesinden sonra çalışmanın ikinci aşamasında katılımcılara geleneksel yöntemlerden anket yöntemi uygulanmıştır. Anket formu; katılımcıların demografik ve tanımlayıcı özellikleri ile
Aaker tarafından geliștirilen marka kişiliği skalası olmak üzere 2 bölümden oluşmuştur. Katılımcılardan ilk bölümde tanımlayıcı ve demografik özelliklerini cevaplamaları istenmiştir. Sonra "Kırmızı Havayolları insan olarak düşünüldüğünde aşağıdaki kişilik özelliklerinden hangisine sahip olurdu?" şeklinde yöneltilen soruyu Aaker'in "Samimiyet, Coşku, Yeterlilik, Çok Yönlülük, Sağlamlık" olarak ifade edilen 5 boyutu ve 42 marka kişiliği sıfatına "1=Kesinlikle Katılmiyorum, 2=Katılmıorum, 3=Kararsızım, 4=Katıliyorum, 5=Kesinlikle Katılıyorum" yargılarına dayandırılan 5'li Likert ölçeğine uygun olarak işaretlemişlerdir. Aynı süreç Sarı Havayolları için de uygulanarak anket formundan elde edilen veriler her iki havayolu için de SPSS Statistics 24.0 programında analiz edilmiştir. Verilen cevapların frekans oranları \%65'in (Öztürk vd., 2018) üzerinde olan kişilik sıfatları ilgili havayolunun kişilik özelliği olarak belirlenmiştir.

\section{Bulgular ve Tartışma}

\subsection{Kırmızı Havayollarına İlişkin EEG ve Anket Sonuçlarının Karşılaştırılması}

Kırmızı Havayollarına ilişkin anket verilerinin frekans analizine tabi tutulması sonucunda marka kişiliği sıfatları belirlenmiştir. Kırmızı Havayolları'nın 5 marka kişiliği boyutunda 40 marka kişiliği sıfatına sahip olduğu saptanmıştır.

Frekans değeri \%65'in üzerindeki kişilik sıfatları Gerçekçi, Aile Odakl, Dürüst, Samimi, Gerçek, Sağlıkl, Orijinal, Neşeli, Duygusal, Arkadaş Canlısı, Cesur, Modaya Uyan, Heyecanll, Canll, Soğukkanll, Genç, Yaratıcl, Eşsiz, Modern (Güncel), Bağımsız, Çăgdaş, Güvenilir, Çalışkan, Güvenli, Zeki, Teknik, Kurumsal, Başarll, Lider, Kendinden Emin, Üst Sınıf, Göz Alıcı(Büyüleyici), Yakışıklı(İyi Görünümlü), Çekici, Düzgün (Muntazam), Dışa Dönük, Erkeksi, Batıll, Çetin (Zorlu), Yalçın (Sağlam) şeklinde belirlenmiştir. Öte yandan Kasabalı (Köylü) ve Kadınsı kişilik sıfatlarının \%65'in altında olmasından ötürü analize dâhil edilmemiştir.

EEG beyin aktivite haritalarını yorumlanması sonucunda katılımcıların Kırmızı Havayollarının marka kişiliğine ilişkin tepkilerinin dalga bölgesi, dalga boyu ve dalga değeri elde edilmiştir. EEG verilerinin yorumlanması sonucunda katılımcıların Kırmızı Havayolları'na ilişkin 5 boyutta 10 kişilik sıfatı (Kasaball, Samimi, Arkadaş Canlısı, Soğukkanlı, Eşsiz, Yaratıcı, Genç, Çekici, Çetin, Sağlam) atfetmiştir. Katılımcıların iki yönteme ilişkin karşılaştırılmalı verileri Tablo 2'de gösterilmiştir.

Tablo 2. Kırmızı Havayolları'nın Marka Kişiliğine İlişkin EEG ve Anket Sonuçlarının Karşılaştırılması

\begin{tabular}{|c|c|c|c|c|}
\hline $\begin{array}{c}\text { Kişilik } \\
\text { Sıfatları }\end{array}$ & EEG & İfade & Frekans & Yüzde \\
\hline \multirow{3}{*}{ Kasabalı } & $\begin{array}{l}\text { Dalga Bölgesi; F7, } \\
\text { F8, P8, F3 }\end{array}$ & Kararsızım & 7 & 21,9 \\
\hline & $\begin{array}{l}\text { Dalga Boyu; 4-7 Hz } \\
\text { Teta }\end{array}$ & Katıliyorum & 3 & 9,4 \\
\hline & $\begin{array}{l}\text { Dalga Değeri: } \\
\text { Normal }\end{array}$ & $\begin{array}{l}\text { Kesinlikle } \\
\text { Katıliyorum }\end{array}$ & 6 & 18,8 \\
\hline \multirow{3}{*}{ Samimi } & $\begin{array}{l}\text { Dalga Bölgesi; } \\
\text { F4,O2 }\end{array}$ & Kararsızım & 5 & 15,6 \\
\hline & $\begin{array}{l}\text { Dalga Boyu; 4-7 Hz } \\
\text { Teta }\end{array}$ & Katıliyorum & 12 & 37,5 \\
\hline & $\begin{array}{l}\text { Dalga Değeri: } \\
\text { Normal }\end{array}$ & $\begin{array}{l}\text { Kesinlikle } \\
\text { Katılıyorum }\end{array}$ & 15 & 46,9 \\
\hline
\end{tabular}




\begin{tabular}{|c|c|c|c|c|}
\hline \multirow{3}{*}{$\begin{array}{l}\text { Arkadaş } \\
\text { Canlısı }\end{array}$} & $\begin{array}{l}\text { Dalga Bölgesi; F5, } \\
\text { F8, FC6, F7 }\end{array}$ & Kararsızım & 3 & 9,4 \\
\hline & $\begin{array}{l}\text { Dalga Boyu; 4-7 Hz } \\
\text { Teta }\end{array}$ & Katıliyorum & 13 & 40,6 \\
\hline & $\begin{array}{l}\text { Dalga Değeri: } \\
\text { Normal }\end{array}$ & $\begin{array}{l}\text { Kesinlikle } \\
\text { Katıliyorum }\end{array}$ & 13 & 40,6 \\
\hline \multirow{3}{*}{ Soğukkanlı } & $\begin{array}{l}\text { Dalga Bölgesi; F4, } \\
\text { FC6, P7 }\end{array}$ & Kararsızım & 7 & 21,9 \\
\hline & $\begin{array}{l}\text { Dalga Boyu; 4-7 Hz } \\
\text { Teta }\end{array}$ & Katıliyorum & 7 & 21,9 \\
\hline & $\begin{array}{l}\text { Dalga Değeri: } \\
\text { Normal }\end{array}$ & $\begin{array}{l}\text { Kesinlikle } \\
\text { Katılıyorum }\end{array}$ & 12 & 37,5 \\
\hline \multirow{3}{*}{ Eşsiz } & $\begin{array}{l}\text { Dalga Bölgesi; F4, } \\
\text { AF3 }\end{array}$ & Kararsızım & 6 & 18,8 \\
\hline & $\begin{array}{l}\text { Dalga Boyu; 4-7 Hz } \\
\text { Teta }\end{array}$ & Katıliyorum & 9 & 28,1 \\
\hline & $\begin{array}{l}\text { Dalga Değeri: } \\
\text { Normal }\end{array}$ & $\begin{array}{l}\text { Kesinlikle } \\
\text { Katılıyorum }\end{array}$ & 12 & 37,5 \\
\hline \multirow{3}{*}{ Yaraticı } & $\begin{array}{l}\text { Dalga Bölgesi; F4, } \\
\text { FC6, F8 }\end{array}$ & Kararsızım & 4 & 12,5 \\
\hline & $\begin{array}{l}\text { Dalga Boyu; 4-7 Hz } \\
\text { Teta }\end{array}$ & Katılıyorum & 6 & 18,8 \\
\hline & $\begin{array}{l}\text { Dalga Değeri: } \\
\text { Normal }\end{array}$ & $\begin{array}{l}\text { Kesinlikle } \\
\text { Katıliyorum }\end{array}$ & 20 & 62,5 \\
\hline \multirow{3}{*}{ Genç } & $\begin{array}{l}\text { Dalga Bölgesi; AF3, } \\
\text { F4, AF4, P8 }\end{array}$ & Kararsızım & 6 & 18,8 \\
\hline & $\begin{array}{l}\text { Dalga Boyu; 4-7 Hz } \\
\text { Teta }\end{array}$ & Katıliyorum & 12 & 37,5 \\
\hline & $\begin{array}{l}\text { Dalga Değeri: } \\
\text { Normal }\end{array}$ & $\begin{array}{l}\text { Kesinlikle } \\
\text { Katıliyorum } \\
\end{array}$ & 13 & 40,6 \\
\hline \multirow{3}{*}{ Çekici } & $\begin{array}{l}\text { Dalga Bölgesi; F4, } \\
\text { F8 }\end{array}$ & Kararsızım & 4 & 12,5 \\
\hline & $\begin{array}{l}\text { Dalga Boyu; 4-7 Hz } \\
\text { Teta }\end{array}$ & Katıliyorum & 12 & 37,5 \\
\hline & $\begin{array}{l}\text { Dalga Değeri: } \\
\text { Normal }\end{array}$ & $\begin{array}{l}\text { Kesinlikle } \\
\text { Katıliyorum }\end{array}$ & 15 & 46,9 \\
\hline \multirow{3}{*}{ Çetin } & $\begin{array}{l}\text { Dalga Bölgesi; F4, } \\
\text { F8, F7 }\end{array}$ & Kararsızım & 11 & 34,4 \\
\hline & $\begin{array}{l}\text { Dalga Boyu; 4-7 Hz } \\
\text { Teta }\end{array}$ & Katıliyorum & 6 & 18,8 \\
\hline & $\begin{array}{l}\text { Dalga Değeri: } \\
\text { Normal }\end{array}$ & $\begin{array}{l}\text { Kesinlikle } \\
\text { Katılıyorum }\end{array}$ & 8 & 25 \\
\hline \multirow{3}{*}{ Sağlam } & $\begin{array}{l}\text { Dalga Bölgesi; F4, } \\
\text { FC6, FC5, P8 }\end{array}$ & Kararsızım & 3 & 9,4 \\
\hline & $\begin{array}{l}\text { Dalga Boyu; 4-7 Hz } \\
\text { Teta }\end{array}$ & Katıliyorum & 13 & 40,6 \\
\hline & $\begin{array}{l}\text { Dalga Değeri: } \\
\text { Normal }\end{array}$ & $\begin{array}{l}\text { Kesinlikle } \\
\text { Katıliyorum }\end{array}$ & 15 & 46,9 \\
\hline
\end{tabular}

4.2. Sarı Havayollarına İlişkin EEG ve Anket sonuçlarının karşılaştırılması

Katılımcıların Sarı Havayolları'na ilişkin anket verilerinin frekans analizine tabi tutulması sonucunda bu havayoluna ilişkin marka kişiliği sıfatları belirlenmiştir. Sarı Havayolları'nın 3 marka kişiliği boyutunda 8 kişilik özelliğine sahip olduğu saptanmıştır. Frekans değeri \%65'in üzerinde olan kişilik özellikleri; Gerçek, Heyecanl, Canl,, Genç, Bağımsız, Çağdaş, Çalışkan, Zeki şeklinde belirlenmiştir. Öte yandan Gerçekçi, Aile Odakl, Kasabalı (Köylü), Dürüst, Samimi, , Sağllkll, Orijinal, Neşeli, Duygusal, Arkadaş Canlisl, Cesur, Modaya Uyan, Soğukkanl, , Yaratıcl, Eşsiz, Modern (Güncel), Güvenilir, Güvenli, Teknik, Kurumsal, Başarlll, Lider, Kendinden Emin, Üst Sinıf, Göz Alıcı(Büyüleyici), Yaklşıklı (İyi Görünümlü), Çekici, Kadınsı, Düzgün (Muntazam), Dışa Dönük, Erkeksi, Batıll, Çetin (Zorlu), Yalçın (Sağlam) kişilik özellikleri frekans analizinde $\% 65$ frekans değerinin altında kalmasından ötürü analize dâhil edilmemiştir.

EEG beyin aktivite haritalarının yorumlanması sonucunda katılımcıların Sarı Havayolları'nın marka kişiliğine ilişkin tepkilerinin dalga bölgesi, dalga boyu ve dalga değeri elde edilmiştir. Katılımcıların Sarı Havayollarına 2 boyutta 4 kişilik sıfatı (Dürüst, Săglıklı, Yaratıcı, Çăğdaş) atfetmiştir. Katılımcıların iki yönteme ilişkin karşılaştırılmalı verileri Tablo 3'te gösterilmiştir.

Tablo 3. Sarı Havayolları'nın Marka Kişiliğine İlişkin EEG ve Anket Sonuçlarının Karşılaştırılması

\begin{tabular}{|c|c|c|c|c|}
\hline \multirow{2}{*}{$\begin{array}{c}\text { Kişilik } \\
\text { Sıfatları } \\
\end{array}$} & \multirow[b]{2}{*}{ EEG } & \multicolumn{3}{|c|}{ Anket } \\
\hline & & İfade & Frekans & Yüzde \\
\hline \multirow{3}{*}{ Dürüst } & $\begin{array}{l}\text { Dalga Bölgesi; AF3, } \\
\text { F7, FC6, F8 }\end{array}$ & Kararsızım & 11 & 34,4 \\
\hline & $\begin{array}{l}\text { Dalga Boyu; 4-7 Hz } \\
\text { Teta }\end{array}$ & Katıliyorum & 11 & 34,4 \\
\hline & $\begin{array}{l}\text { Dalga Değeri: } \\
\text { Normal }\end{array}$ & $\begin{array}{l}\text { Kesinlikle } \\
\text { Katılıyorum }\end{array}$ & 4 & 12,5 \\
\hline \multirow{3}{*}{ Sağlıklı } & $\begin{array}{l}\text { Dalga Bölgesi; F3, } \\
\text { FC5, O2 }\end{array}$ & Kararsızım & 8 & 25 \\
\hline & $\begin{array}{l}\text { Dalga Boyu; 4-7 Hz } \\
\text { Teta }\end{array}$ & Katıliyorum & 14 & 43,8 \\
\hline & $\begin{array}{l}\text { Dalga Değeri: } \\
\text { Normal }\end{array}$ & $\begin{array}{l}\text { Kesinlikle } \\
\text { Katılıyorum }\end{array}$ & 2 & 6,3 \\
\hline \multirow{3}{*}{ Yaraticı } & $\begin{array}{l}\text { Dalga Bölgesi; P8, } \\
\text { F7, O1 }\end{array}$ & Kararsızım & 9 & 28,1 \\
\hline & $\begin{array}{l}\text { Dalga Boyu; 4-7 Hz } \\
\text { Teta }\end{array}$ & Katıliyorum & 10 & 31,3 \\
\hline & $\begin{array}{l}\text { Dalga Değeri: } \\
\text { Normal }\end{array}$ & $\begin{array}{l}\text { Kesinlikle } \\
\text { Katılıyorum }\end{array}$ & 2 & 6,3 \\
\hline \multirow{3}{*}{ Çağdaş } & $\begin{array}{l}\text { Dalga Bölgesi; F3, } \\
\text { FC6, F8 }\end{array}$ & Kararsızım & 8 & 25 \\
\hline & $\begin{array}{l}\text { Dalga Boyu; 4-7 Hz } \\
\text { Teta }\end{array}$ & Katıliyorum & 13 & 40,6 \\
\hline & $\begin{array}{l}\text { Dalga Değeri: } \\
\text { Normal }\end{array}$ & $\begin{array}{l}\text { Kesinlikle } \\
\text { Katıliyorum }\end{array}$ & 5 & 15,6 \\
\hline
\end{tabular}

\subsection{Sarı ve Kırmızı Havayolları'na İlişkin Anket ve EEG Analiz Sonuçlarının Karşılaştırılması}

Araştırmada incelenen her iki havayolunun marka kişiliğine ilişkin anket yöntemi ve EEG analiz yöntemi sonuçları karşılaştırılmalı olarak verilmiştir. $\mathrm{Bu}$ sonuçlara göre; Kırmızı Havayollarının anket yöntemine göre frekans analizi sonucunda 5 boyutta 40 kişilik sıfatından, EEG analiz yöntemi sonucunda ise; 4 boyutta 11 kişilik sıfatından oluştuğu belirlenmiştir. Diğer taraftan, Sarı Havayollarının anket yöntemine göre frekans analizi sonucunda 3 boyutta 8 kişilik sıfatından, EEG analiz yöntemi sonucunda ise; 2 boyutta 4 kişilik sıfatından oluştuğu belirlenmiştir (Tablo4).

Kırmızı Havayolları'nın EEG analiz yönteminden elde edilen veriler anket yönteminden elde edilen verileri büyük oranda desteklemiştir. EEG analiz yöntemi sonuçları anket sonuçlarını filtrelemiş ve daha gerçekçi sonuçların elde edilmesini sağlamıştır. Ancak, Sarı Havayolları'ndan elde edilen verilerin Kırmızı Havayolları'ndan elde edilen veriler gibi paralellik göstermediği görülmüştür. Sarı Havayolları'nın marka kişiliğine ilişkin verilen yanıtlar ile beyinsel tepki sonuçları neredeyse birbirinden ayrı sonuçlar vermiştir. Sarı Havayolları'nın marka kişiliğine ilişkin anket ve EEG analiz sonuçları katılımcıların yazılı beyanları ile gerçekteki düşüncelerinin farklı olduğu varsayımını destekler nitelikte olmuştur. 
Tablo 4. Kırmızı Havayolları ve Sarı Havayolları'nın Marka Kişiliğine İlişkin EEG ve Anket sonuçlarının Karşılaştırılması

\begin{tabular}{|c|c|c|c|c|}
\hline \multirow{2}{*}{ MARKA KİŞiLIĞİ BOYUTLARI } & \multicolumn{2}{|c|}{ Kırmızı Havayolları } & \multicolumn{2}{|c|}{ Sarı Havayolları } \\
\hline & ANKET & EEG & ANKET & EEG \\
\hline Samimiyet & $\begin{array}{c}\text { Gerçekçi, Aile odaklı, Dürüst, } \\
\text { Samimi, Gerçek, Sağlıklı, } \\
\text { Orijinal, Neşeli, Duygusal, } \\
\text { Arkadaş Canlısı }\end{array}$ & $\begin{array}{c}\text { Kasabalı, Samimi, Arkadaş } \\
\text { Canlısı }\end{array}$ & Gerçek & Dürüst, Sağlıklı \\
\hline Coşku & $\begin{array}{l}\text { Cesur, Modaya Uyan, } \\
\text { Heyecanlı, Canlı, Soğukkanlı, } \\
\text { Yaratıcı, Eşsiz, Modern, } \\
\text { Bağımsız, Çağdaş }\end{array}$ & $\begin{array}{c}\text { Soğukkanl,, Eşsiz, Yaratıcı, } \\
\text { Genç }\end{array}$ & $\begin{array}{l}\text { Heyecanlı, Canlı, Genç, } \\
\text { Bağımsız, Çağdaş }\end{array}$ & Yaratıcı, Çağdaş \\
\hline Yeterlilik & $\begin{array}{l}\text { Güvenilir, Çalışkan, } \\
\text { EmniyetliZeki, Teknik, } \\
\text { KurumsalBaşarılı, Lider, } \\
\text { Kendinden Emin, Genç }\end{array}$ & ----- & -------. & ------- \\
\hline
\end{tabular}

Çok Yönlülük

Üst Sınıf, Göz Alıcı, Yakışıklı,

Çekici, Düzgün

Çekici

\section{.}


konforun yanında emniyetli ve güvenilir bir taşımacılık türü olmasından dolayı bu boyut içerisinde yer alan güvenilir, emniyetli ve kurumsal gibi marka kişiliği sıfatlarına sahip olmamasının hizmet kalitesi algısını olumsuz yönde etkileyeceği düşünülmektedir.

Diğer yandan Sarı Havayolları'na 'samimiyet ve coşku' boyutunda kişilik özellikleri atfedildiği, çok yönlülük, yeterlilik ve sağlamlık boyutlarında ise kişilik özelliklerinin atfedilmediği görülmüştür. Sarı Havayolları Türkiye'de düşük maliyetli taşıyıcılık modeli ile maliyet ve temel uçuş hizmetine odaklanarak faaliyet gösteren bir havayolu işletmesidir. Ancak, Sarı Havayolları'na da Kırmızı Havayolları gibi 'yeterlilik' boyutunda kişilik özellikleri atfedilmemesi dikkat çekicidir. Sarı Havayolları için düşük maliyetli taşıyıcı olmasının yanında güvenilir ve emniyetli kişilik sıfatlarını barındıran 'yeterlilik' boyutunda kişilik atfedilmesinin bu iş modeline ilişkin pozitif algıyı güçlendireceği tahmin edilmektedir.

Araştırmanın sonucunda anket yöntemi ile EEG yönteminden elde edilen sonuçlar arasında bir takım farklılıklar ortaya çıkmış ve anket yönteminde her iki havayoluna da daha fazla marka kişiliği sıfatı atfedilmiştir. $\mathrm{Bu}$ farklılıklar katılımcıların sahip olduğu bilinçli ya da bilinçsiz ön yargılarla açıklanabilmektedir. Katılımcılar sözlü veya yazılı beyanları esnasındaduygularının etkisinde kalarak sorulara taraflı cevaplar verebilmektedir. $\mathrm{Bu}$ durumda farkında olarak ya da olmayarak araştırmaların güvenirlik ve geçerliliğini etkilemektedir(Erdemir ve Yavuz, 2016).Dolayısıyla EEG yönteminden elde edilen bulguların daha doğru ve gerçekçi olduğundan söz edilebilmektedir. Ayrıca, EEG yönteminin anket yöntemi ile kıyaslandığı zaman "filtre" görevi gördüğü ve daha anlamlı sonuçların elde edilmesini sağladığı söylenebilir. Nitekim Öztürk vd.'nin(2018) yaptıkları çalışma da busonucu destekler niteliktedir. Öte yandan geleneksel yöntemlerin nöropazarlama yöntemleri ile birlikte uygulanmasının çalışmaların etkinliğini artıracağ önerilmektedir. Bu çalışmanın; akademik anlamda havayolu pazarlaması literatüründe yapılmış ilk çalışmalardan biri olması sebebiyle havacılık ve pazarlama alanına katkı sağlayacağı öngörülmektedir. Ayrıca, havayolu hizmet kalitesi ve marka algısı gibi ölçümlenmesi zor alanlara ilişkin boşlukların ortaya çıkarılması konusunda yol göstereceği düşünülmektedir.

\section{Kaynakça}

Aaker, J. L. (1997). Dimension of Brand Personality. Journal of Marketing Research, 34(3), 347-356.

Akın, M. S., \& Sütütemiz, N. (2014). Nöropazarlama ve Uygulamacıların Perspektifinden Etik Yönü. Uluslarası Işletme ve Yönetim Dergisi, 2(1), 67-83.

Astolfi, L., Fallani, F. D., Cincotti, F., Mattia, D., Bianchi, L., Marciani, M. G., . . . Colosimo, A. (2008). Neural Basis for Brain Responses to TV Commercials: A HighResolution EEG Study. IEEE Transactions on Neural Systems and Rehabilitation Engineering, 16(6), 522531.
Aysan, E., Yaylı, A., \& Helvacı, E. (2012). Üniversitelerin Marka Kişiliği Algısının Belirlenmesi Üzerine Bir Araştırma. İşletme Araştırmaları Dergisi, 4(4), 182-204.

Azoulay, A., \& Kapferer, J. (2003). Do Brand Personality Scales Really Measure Brand Personality? Journal of Brand Management, 11(2), 143-155.

Barré, J., Afonso-Jaco, A., Buisine, S., \& Aoussat, A. (2015). Brain Imaging And Product Design: Towards New Evaluation Methods. Le Travail Humain, 78(3), 217-238.

Bercea, M. D. (2013). Anatomy of methodologies for measuring consumer behavior in neuromarketing research. Proceedings of the Lupcon Center for Business Research (LCBR) European Marketing Conference, (s. 1-14). Ebermannstadt.

Berčík, J., E. Horská, W. W., \& Chen, Y. (2015). How can food retailing benefit from neuromarketing research: a case of various parameters of store illumination and consumer response. Consumer Behavior in a Changing World: Food, Culture, Society. Napoli.

Boksem, M. A., \& Smidts, A. (2015). Brain Responses To Movie Trailers Predict İndividual Preferences For Movies And Their Population-Wide Commercial Success. Journal of Marketing Research, 52(4), 482492.

Boyraz, E., \& Balım, O. (2015). Nasıl Bir Parti? Seçmenlerin Siyasal Marka Kişiliği Algısı Üzerine Bir Araştırma: Tokat İli Örneği. Süleyman Demirel Üniversitesi Iktisadi ve İdari Bilimler Fakültesi Dergisí, 20(4), 347-367.

Choi, Y., Kwon, N., Lee, S., Shin, Y., Ryo, C. Y., Park, J., \& Shin, D. (2014). Hypovigilance Detection for UCAV Operators Based on a Hidden Markov Mode. Computational and Mathematical Methods in Medicine, 2014, 1-13.

Çakar, T. (2011, 02 01). Nöropazarlamanın Klsa'clk Tarihi. $\quad 08 \quad 08, \quad 2018 \quad$ tarihinde http://www.iktisadiyat.com/2011/02/01/npyd-6noropazarlamanin-kisacik-tarihi/ adresinden alındı

Erdemir, K. O., \& Yavuz, Ö. (2016). Nöropazarlama'ya Giriş. İstanbul: Brand Map.

Fisher, C. E., Chin, L., \& Klitzman, R. (2010). Defining Neuromarketing: Practices And Professional Challenges. Harv Rev Psychiatry, 18(4), 230-237.

Fortunato, V. C., Giraldi, J. d., \& Oliveira, J. H. (2014). A Review of Studies on Neuromarketing: Practical Results, Techniques, Contributions and Limitations . Journal of Management Research , 6(2), 201-220.

Freeman, W. J., \& Quiroga, R. Q. (2013). Imagining Brain Function With EEG. New York : Springer Science Business Media.

Genco, S. J., Pohlmann, A. P., \& Steidl, P. (2013). Neuromarketing For Dummies. Mississagua: John Wiley and Sons. 
Hansen, P., Kringelbach, M., \& Salmelin, R. (2010). MEG an Introduction to Methods. New York: Oxford University Press.

Hillenbrand, P., Alcauter, S., Cervantes, J., \& Barrios, F. (2013). Better Branding: Brand Names Can Influence Consumer Choice. Journal of Product \& Brand Management, 22(4), 300-308.

Hsu, M. (2017). Neuromarketing: Inside the Mind of the Consumer. California Management Review, 59(4), 5-22.

Kalemci, G. (2015). Tüketicilerde Marka Kişiliği Algısının Analizine İlişkin Hijyenik Ürünler Sektöründe Bir Uygulama. Dumlupınar Sosyal Bilimler Dergisi(24).

Karoubi, M., \& Noghan, S. A. (2014). Investigating Brand Personality Of State-Owned And Private Airlines: Maham Versus Iran Air. Management Science Letters, 4, 1245-1254.

Khushaba, R., Wise, C., Kodagoda, S., Louviere, J., E.Kahn, B., \& Townsend, C. (2013). Consumer Neuroscience: Assessing The Brain Response To Marketing Stimuli Using Electroencephalogram (EEG) And Eye Tracking. Expert Systems with Applications, 40(9), 3803-3812.

Knutson, B., Rick, S., Wimmer, G., \& Prelec, D. (2007). Neural Predictors Of Purchases. Neuron, 53(1), 147156.

Kotler, P. (2011). Pazarlama 3.0 Ürün, Müsteri, Insan Ruhu. İstanbul: Optimist Yayınları.

Kotsi, F., \& Valek, N. S. (2018). Flying With Nicole Kidman or Jennifer Aniston? Brand Funnel Stages' Influence On Brand Personality. Journal of Travel \& Tourism Marketing, 35(3), 365-376.

Lee, N., Broderick, A. J., \& Chamberlain, L. (2007). What Is 'Neuromarketing'? A Discussion And Agenda For Future Research. International Journal of Psychophysiology, 63(2), 199-204.

Lee, N., Chamberlain, L., \& Brandes, L. (2017). Welcome to the jungle! The neuromarketing literature through the eyes of a newcomer. European Journal of Marketing, 52(1), 4-38.

Lin, C., Tuan, H., \& Chiu, Y. (2010). Medial Frontal Activity in Brand-Loyal Consumers: A Behavior And Near-Infrared Ray Study. Journal of Neuroscience, Psychology, and Economics, 3(2), 59-73.

Ma, Q., Wang, K., X Wang, Wang, C., \& Wang, L. (2010). The Influence Of Negative Emotion On Brand Extension As Reflected By The Change of N2: A Preliminary Study . Neuroscience Letters, 485(3), 237 240.

Ma, Q., Wang, X., Shu, L., \& Dai, S. (2008). P300 and Categorization In Brand Extension. Neuroscience Letters, 431(1), 57-61.

McClure, S. M., Li, J., Tomlin, D., S.Cypert, K., Montague, L. M., \& Montague, P. (2004). Neural Correlates of Behavioral Preference for Culturally Familiar Drinks. Neuron, 44(2), 379-387.
Mehmood, R. M., \& Lee, H. J. (2016). Towards human brain signal preprocessing and artifact rejection methods. Int'l Conf. Biomedical Engineering and Sciences (BIOENG'16), (s. 27-31). Las Vegas.

Morris, J. D., Klahr, N. J., Shen, F., \& Villegas, J. (2009). Mapping a Multidimensional Emotion in Response. Human Brain Mapping to Television Commercials, 30, 789-796.

Ohme, R., Reykowska, D., Wiener, D., \& Choromanska, A. (2009). Analysis of Neurophysiological Reactions to Advertising Stimuliby Means of EEG and Galvanic Skin Response Measures. Journal of Neuroscience, Psychology and Economic, 2(1), 21-31.

Özdoğan, B. (2008). Göz İzleme ve Pazarlamada Kullanılması Üzerine Kavramsal Bir Çalışma. Ticaret ve Turizm Eğitim Fakültesi Dergisi(2), 134-147.

Özer, S. U., \& Ersoy, E. G. (2012). Türkiye'de Faaliyet Gösteren Havayolu Şirketlerinin Marka Kişiliklerini Belirlemeye Yönelik Bir Araştırma. Turizm Araştırmaları Dergis, 23(2), 173 - 186.

Özkara, B. Y. (2017). Nöropazarlamada Elektroensefalografi (EEG) Kullanımı. Ankara: Ekin Yayınevi.

Öztürk, S., Bayır, T., \& Yücel, N. (2018). Does the Brain and Tongue Speak the Same? Comparison of Survey and EEG Methods: A Study on the Measurement of the Brand Personality. Pazarlama Teorisi ve Uygulamalar Dergisi, 4(1), 139-176.

Po, N. A., Iorga, A., \& Pelau, C. (2013). Process, Using Neuromarketing Studies to Explore Emotional Intelligence-as a key to the Buying Decision. European Conference on Knowledge Management, (s. 1-8). Bucharest.

Poldrack, R. A., Mumford, J. A., \& Nichols, T. E. (2011). Handbook of Functional MRI Data Analysis. New York: Cambridge Universty Press.

Sadedil, S. N. (2016). Pazarlama Mesajlarının Etkinliği Açısından Geleneksel Pazarlama Araştırmaları Ile Nöropazarlama araştırmalarının Karşılaştırılması; "Sigara Paketleri Üzerindeki Caydırıcı Mesajların, Sigara Kullanma Alışkanlıkları Üzerindeki Etkisi. (Yayınlanmamış Doktora Tezi) Marmara Üniversitesi: İstanbul.

Sands, S. F. (2009). Sample Size Analysis for Brainwave Collection (EEG) Methodologies. http://www.sandsresearch.com/assets/white-paper.pdf adresinden alınd 1

Santos, J., Seixas, D., Brandão, S., \& Moutinho, L. (2011). Investigating The Role of The Ventromedial Prefrontal Cortex In The Assessment Of Brands. Frontiers in neuroscience, 5, 77.

Shamir, B., \& Ahmadi, S. (2016). Evaluating The Effectiveness Of Neuro Web Design Model İn Business Websites (Observational Study). Iranian journal of Information Processing \& Management, 31(3), 767784. 
Taqwa, T., Suhendra, A., Hermita, M., \& Darmayantie, A. (2015). Implementation Of Naïve Bayes Method For Product Purchasing Decision Using Neural Impulse Actuator In Neuromarketing. Surabaya, Indonesia.

Tüzel, N. (2010). Tüketicilerin Zihnini Okumak: Nöropazarlama ve Reklam. Marmara İletişim Dergisi (10), 163-176.

Ural, T. (2008). Pazarlamada Yeni Bir Yaklaşım; Nöropazarlama Üzerine Kuramsal Bir Değerlendirme. Ç.Ü. Sosyal Bilimler Enstitüsü Dergisi, 17(2), 421-432.

Uztuğ, F. (2003). Markan Kadar Konuş. İstanbul: MediaCat Yayınları.

Vecchiato, G., Toppi, J., Astolfi, L., Fallani, F. d., Cincotti, F., Mattia, D., .. . Babiloni, F. (2011). Spectral EEG Frontal Asymmetries Correlate With The Experienced Pleasantness Of Tv Commercial Advertisements. Medical \& Biological Engineering \& Computing, 49(5), 579-583.

Wang, X., Ma, Q., \& Wang, C. (2012). N400 As An Index Of Uncontrolled Categorization Processing In Brand Extension. Neuroscience Letters, 525(1), 76-81.
Yener, D. (2007). Marka Çă̆rışım Unsurlarının Marka Kişiliği Üzerine Etkisi: Sütaş Markası Üzerine Bir Uygulama. (Yayınlanmamış Yüksek Lisans Tezi) İstanbul: Marmara Üniversitesi.

Yoon, C., Gutchess, A., \& Feinberg, F. (2006). A Functional Magnetic Resonance Imaging Study of Neural Dissociations Between Brand And Person Judgments. Journal of Consumer Research, 33(1), 3140.

Yücel, A., \& Çubuk, F. (2014). Bir Nöropazarlama Araştırmasının Deneysel Yolculuğu ve Araştırmanın İlk İpuçları. Fırat Üniversitesi Sosyal Bilimler Dergisi, 24(2), 133-149.

Yücel, N. (2016). Pazarlamada Yeni Bir Trend Nöropazarlama ve Uygulamaları. Çanakkale: Paradigma Akademi.

Yücel, N., \& Halifeoğlu, M. (2017). Marka Kişiliği Algısı: Sosyal Medya MArkaları Üzerine Üniversite Öğrencilerine Yönelik Bir Araştırma. Fırat Üniversitesi Sosyal Bilimler Dergisi, 27(2), 177-191. 
